\title{
KUALITAS NUGGET AYAM DENGAN BAHAN PENGISI TEPUNG PATI UBI KAYU (Manihot utilissima) DAN TEPUNG SAGU (Metroxylon sagu Rottb.) LOKAL PROVINSI MALUKU UTARA
}

\section{The Quality of Chicken Nugget with Local Fillers from Cassava Flour (Manihot utilissima) and Sago Flour (Metroxylon sagu Rottb.) of North Maluku Province}

\author{
Yusnaini B. Talebe ${ }^{1}$, Indah Rodianawati ${ }^{2}$, dan Eka Kusuma Dewi ${ }^{3}$ \\ 1 Program Studi Peternakan, Fakultas Pertanian, Universitas Khairun \\ 2Program Studi Teknologi Hasil Pertanian, Fakultas Pertanian, Universitas Khairun \\ 3 Program Studi Agribisnis, Fakultas Pertanian, Universitas Khairun \\ Email: yusnaini@unkhair.ac.id
}

\begin{abstract}
ABSTRAK
Penelitian ini bertujuan untuk mengkaji sifat fisik, kimia, dan organoleptik nugget ayam dengan bahan pengisi tepung pati ubi kayu dan tepung sagu dengan persentase yang berbeda. Perlakuan bahan pengisi yang digunakan pada penelitian ini yaitu P1 (100\% tepung pati ubi kayu), P2 (75\% tepung pati ubi kayu dan 25\% tepung sagu), P3 (50\% tepung pati ubi kayu dan 50\% tepung sagu), P4 (25\% tepung pati ubi kayu dan 75\% tepung sagu), dan P5 (100\% tepung sagu). Penelitian ini dilakukan menggunakan rancangan acak lengkap (RAL) dengan 3 kali ulangan. Sifat fisik yang diuji yaitu daya ikat air, nilai kekerasan, stabilitas emulsi, dan nilai pH. Sifat kimia yang diuji yaitu kadar air, protein, lemak, karbohidrat, dan abu. Sifat organoleptik diuji dengan uji hedonik (penampakan warna, aroma, rasa, dan tekstur). Data hasil uji sifat fisik dan kimia dianalisis dengan sidik ragam dan diuji lanjut dengan BNT. Data hasil uji sifat organoleptik dianalisis statistik non parametrik dengan uji Hedonic Kurskal Wallis dan diuji lanjut dengan Multiple Comparisson of Mean Rank Test. Hasil penelitian menunjukkan bahwa nugget ayam dengan bahan pengisi $100 \%$ tepung pati ubi kayu mempunyai sifat fisik yang lebih bagus dengan daya ikat air paling besar 47,30\%, tingkat kekerasan paling rendah 676,22 gF, dan nilai pH paling mendekati normal 5,23. Sifat kimia nugget yang mendekati persyaratan nugget ayam menurut SNI adalah nugget dengan bahan pengisi 25\% tepung pati ubi kayu dan 75\% tepung sagu. Sifat organoleptik menunjukkan bahwa nugget yang mengandung bahan pengisi 100\% tepung pati ubi kayu yang paling diterima oleh panelis. Kesimpulan yang dapat diambil bahwa tepung pati ubi kayu dan tepung sagu lokal di Provinsi Maluku Utara dapat dijadikan sebagai bahan pengisi nugget ayam. Tepung pati ubi kayu lokal dapat menggantikan 100\% tepung tapioka komersil dan tepung sagu dapat mensubtitusi hingga 50\% untuk mendapatkan nugget sesuai standar.
\end{abstract}

Kata kunci: Bahan Pengisi, Nugget Ayam, Tepung Pati Ubi Kayu, Tepung Sagu

\begin{abstract}
This study aims to examine the physical, chemical, and organoleptic properties of chicken nuggets with different percentages of cassava and sago starch as fillers. The treatment of fillers used were P1 (100\% cassava starch), P2 (75\% cassava starch and 25\% sago starch), P3 (50\% cassava starch and 50\% sago flour), P4. (25\% cassava starch and 75\% sago flour), and P5 (100\% sago starch). This research was conducted with an experimental method using a completely randomized design (CRD) with 3 replications. The physical properties tested water-holding capacity, hardness value, emulsion stability, and $p H$ value. The
\end{abstract}


chemical properties tested moisture, protein, fat, carbohydrate, and ash content. Organoleptic properties were tested with a hedonic test (color, aroma, taste, and texture). The data of physical and chemical characteristics were analyzed by means of variance and further tested by the LSD test. Organoleptic results were analyzed statistically non-parametric with the Hedonic Kurskal Wallis test and further tested with the Multiple Comparison of Mean Rank Test. The results showed that chicken nuggets with 100\% filler of cassava starch flour had better physical properties with the greatest water binding capacity 47.30\%, the lowest hardness level $676.22 \mathrm{gF}$, and the $\mathrm{pH}$ value that closest to normal 5.23. The chemical properties of nuggets that closed to the SNI were nuggets with 25\% cassava starch and 75\% sago starch. The organoleptic properties showed that nuggets containing 100\% filler of cassava starch were the most accepted by the panelists. The conclusion is that cassava starch and local sago flour in North Maluku Province can be used as filler for chicken nuggets. Local cassava flour can replace 100\% commercial tapioca flour and sago flour can substitute up to $50 \%$ to get nuggets that comply with the standard.

Keywords: Fillers, Chicken Nugget, Cassava Flour, Sago Flour

\section{PENDAHULUAN}

Nugget merupakan salah satu olahan daging yang dikenal masyarat saat ini. Nugget termasuk produk olahan beku siap saji. Menurut USDA (1991) bahwa lapisan nugget harus lebih ringan dari berat produk. Kualitas nugget dapat dipengaruhi oleh proses pengolahan, bahan baku dan bahan tambahan, juga nilai gizi maupun secara keseluruhan akseptabilitas konsumen. Nugget adalah produk daging giling yang dibumbui, lalu diberi perekat tepung, pelumuran tepung roti (breading), dan digoreng setengah matang lalu dibekukan untuk mempertahankan mutunya selama penyimpanan (Tanoto, 1994).

Proses pembuatan nugget, bahan pengisi yang digunakan adalah tepung pati. Pati mempunyai rasa tidak manis, tidak larut dalam air dingin tetapi dalam air panas dapat membentuk gel yang bersifat kental (deMan, 1997). Tepung yang biasa digunakan dalam proses pembuatan nugget misalnya tepung terigu, tepung maizena, dan tepung pati ubi kayu. Bahan pengisi yang umumnya digunakan pada pembuatan nugget adalah tepung terigu, karena tepung terigu mengandung gluten yang membantu terbentuknya tekstur dan kekenyalan pada produk (Kusumaningrum, 2013). Tepung maizena mengandung kandungan vitamin A dan protein 9,2\% (Suarni, 2009).

Menurut Muljohardjo (1987) pati ubi kayu merupakan hasil ekstraksi ubi kayu yang telah mengalami proses ekstraksi sempurna dan dilanjutkan dengan proses pengeringan. Tepung pati ubi kayu ini mempunyai sifat-sifat yang sangat potensial untuk dimanfaatkan dalam industri pangan, diantaranya sebagai pengental (thickener), pengisi (filler), bahan pengikat (binder) dan sebagai bahan penstabil (stabilizer). Selain itu, pati ubi kayu juga bisa dijadikan sebagai bahan pembentuk edible film. Selain tepung ubi kayu, tepung sagu juga dapat digunakan sebagai bahan pengisi. Pati tepung sagu dapat memperbaiki kekenyalan nugget karena memiliki kandungan amilosa pati yang berperan dalam pembentukan gel dan memperbaiki kekenyalan pada nugget.

Penggunaan tepung sebagai bahan pengisi pada nugget telah dilakukan oleh Sakul dan Komansilan (2018) menggunakan tepung tapioka, tepung sagu, tepung maizena, dan tepung beras ketan. Kusumaningrum dkk. (2013) menggunakan tepung terigu, tepung ubi jalar kuning, tepung gaplek, tepung garut, dan tepung mocaf (modified cassava flour) sebagai bahan pengisi pada nugget. Awaliah dkk. (2017) menggunakan tepung sagu, tepung maizena, dan tepung terigu sebagai bahan pengisi pada nugget. Rieuwpassa (2016) menggunakan tepung sagu sebagai bahan pengisi pada nugget. 
Tepung pati ubi kayu dan tepung sagu digunakan sebagai bahan pengental, bahan pengisi dan pengikat dalam industri makanan. Sebagai makanan pokok, sagu umumnya diolah menjadi papeda, sinoli (karu-karu), serta sagu lempeng. Sebagai makanan jajanan, sagu umumnya diolah menjadi talam manis, talam asin, onglo-onglo, sagu kenari, sagu kepala, sagu kenari kelapa, bubur mutiara, bubur sagu (buburne), bagea, sagon kukus, sagu manis, sagu redang, sagu embal, laksa sagu, sagu baker, mie, dan cendol (Astawan, 2004).

Tepung pati ubi kayu dan sagu banyak di produksi di Maluku Utara. Tepung pati ubi kayu dan sagu di Maluku Utara merupakan bahan baku pembuatan masakan khas yaitu peda (popeda). Proses pembuatan tepung dan cara penjualannya masih secara tradisioanal. Komponen yang paling dominan dalam tepung pati ubi kayu dan sagu adalah pati (karbohidrat) yang dapat digunakan sebagai bahan pengisi namun mesti dipelajari kualitas seperti sifat fisik, kimia, dan organoleptik dengan uji hedonik terhadap nugget ayam yang menggunakan bahan pengisi tepung pati ubi kayu dan sagu lokal dari Provinsi Maluku Utara dengan persentase yang berbeda.

\section{METODE}

\section{Bahan}

Bahan-bahan yang digunakan pada penelitian ini adalah daging ayam broiler, tepung pati ubi kayu, tepung sagu, susu skim, tepung roti, telur, roti, dan bumbu-bumbu.

\section{Rancangan Penelitian}

Penelitian ini dilakukan dngan metode eksperimental dengan menggunakan rancangan acak lengkap (RAL) dengan 3 ulangan. Faktor yang diuji pada penelitian ini adalah perbedaan persentase tepung pati ubi kayu dan tepung sagu pada nugget ayam. Perlakuan bahan pengisi yang digunakan pada penelitian ini yaitu P1 (100\% tepung pati ubi kayu), P2 (75\% tepung pati ubi kayu dan 25\% tepung sagu), P3 (50\% tepung pati ubi kayu dan 50\% tepung sagu), P4 (25\% tepung pati ubi kayu dan $75 \%$ tepung sagu), dan P5 (100\% tepung sagu).

\section{Metodologi}

Daging ayam broiler dipisahkan dari kulit dan tulang serta jaringan ikat. Daging kemudian ditimbang sesuai dengan kebutuhan tiap perlakuan. Bahan-bahan pengisi ditimbang sesuai dengan perlakuan dan dilakukan penimbangan bahan-bahan lainnya. Daging ayam dan bahan-bahan lain dimasukkan ke food processor kemudian dicampur selama 2 menit hingga bahan-bahan tercampur homogen. Adonan tersebut terlebih dahulu ditimbang sebelum dicetak dalam loyang aluminium dan dikukus selama 10 menit. Setelah nugget masak dilakukan proses pendinginan pada suhu ruang dan kemudian dicetak. Tahap terakhir sebelum pemasukan dalam freezer adalah nugget dilumuri dengan tepung roti.

\section{Parameter}

Parameter yang diamati adalah sifat fisik, kimia, dan organoleptik nugget ayam. Pengujian sifak fisik antara lain daya ikat air (Soeparno, 1998), nilai kekeraan (Kilcast dan Eves, 1993), stabilitas emulsi (Carpenter dan Saffle, 1994) dan nilai pH (Ockerman, 1983). Sifat kimia antara lain kadar air (motode oven), abu (alat muffle furnance), protein (mikro kjedahl), dan lemak (metode soxhlet), dan karbohidrat (AOAC, 1990; Sudarmadji et al., 1997). Sifat organoleptik diamati dengan uji hedonik meliputi 
penampakan warna, aroma, rasa, dan tekstur. Penilaian menggunakan skala hedonik 1-5 yaitu dari sangat suka (5) sampai sangat tidak suka (1). Pengujian dilakukan dengan menggunakan 50 orang panelis tidak terlatih.

Analisis Statistik

Data hasil uji sifat fisik dan kimia dianalisis dengan sidik ragam menggunakan rancangan acak lengkap (RAL) dan diuji lanjut dengan uji BNT (Steel dan Torrie, 1995). Data hasil uji sifat organoleptik dianalisis statistik non parametrik dengan uji Hedonic Kurskal Wallis dan diuji lanjut dengan uji banding rataan ranking (multiple comparisson of mean rank test).

\section{HASIL DAN PEMBAHASAN}

\section{Sifat Fisik}

Pengujian yang dilakukan terhadap sifat fisik nugget antara lain daya ikat air, tingkat kekerasan, stabilitas emulsi, dan nilai pH nugget. Hasil pengujian sifat fisik nugget ayam disajikan pada Tabel 1.

Tabel 1. Hasil Analisis Sifat Fisik Nugget Ayam

\begin{tabular}{lccccc}
\hline \multirow{2}{*}{ Parameter } & \multicolumn{5}{c}{ Perlakuan } \\
\cline { 2 - 6 } & $\mathrm{P} 1$ & $\mathrm{P} 2$ & $\mathrm{P} 3$ & $\mathrm{P} 4$ & $\mathrm{P} 5$ \\
\hline Daya ikat air (\%) & $47,30^{\mathrm{a}}$ & $33,13^{\mathrm{b}}$ & $36,86^{\mathrm{bc}}$ & $44,96^{\mathrm{a}}$ & $25,26^{\mathrm{d}}$ \\
Tingkat kekerasan (gf) $^{\mathrm{ns}}$ & 676,22 & 843,64 & 748,45 & 801,54 & 993,99 \\
Stabilitas emulsi (ml)ns & 0,33 & 0,47 & 0,53 & 0,45 & 0,28 \\
Nilai pH & $5,23^{\mathrm{a}}$ & $5,08^{\mathrm{b}}$ & $5,14 \mathrm{bc}$ & $4,93^{\mathrm{a}}$ & $4^{\mathrm{b}}, 99^{\mathrm{d}}$ \\
\hline abcd Superskrip yang berbeda pada baris yang sama menunjukkan perbedaan yang nyata (P<0,05) \\
NsNon signifikan
\end{tabular}

\section{Daya ikat air}

Hasil analisis sidik ragam menunjukkan bahwa perbedaan persentase bahan pengisi nugget ayam berpengaruh nyata $(\mathrm{P}<0,05)$ terhadap daya ikat air nugget. Daya ikat air nugget ayam berkisar antara 25,26 sampai 47,30\%. Daya ikat air nugget tertinggi diperoleh dengan bahan pengisi $100 \%$ tepung pati ubi kayu, sedangkan daya ikat air nugget terendah dengan perlakuan bahan pengisi $100 \%$ tepung sagu. Hal ini disebabkan karena perbedaan bahan pengisi dipengaruhi oleh jenis bahan tepung yang digunakan serta kandungan pati yang ada di masing-masing jenis tepung. Tepung pati ubi kayu memiliki kemampuan untuk mengikat air yang lebih tinggi dariapda tepung sagu. Winarno menyatakan jika suspensi pati dalam air dipanaskan, maka akan terjadi beberapa perubahan. Fardiaz et al (1992) menyatakan bahwa pati mentah (tanpa proses pemanasan) hanya akan menyerap air kira-kira sepertiga dari berat dayanya, tetapi jika dipanaskan maka akan menyerap air beberapa kali dan ukurannya akan bertambah beberapa kali lipat dari ukuran semula.

\section{Tingkat Kekerasan}

Nilai rataan tingkat kekerasan nugget ayam berkisar antara 676,22 sampai 993,99 gf. Rataan tingkat kekerasan tertinggi diperoleh nugget dengan bahan pengisi $100 \%$ tepung sagu dan yang terendah pada nugget bahan pengisi $100 \%$ tepung pati ubi kayu. Perbedaan nilai kekerasan pada nugget ayam ini disebabkan oleh perbedaan kadar air dalam produk dan jenis tepung yang digunakan. Walaupun analisis sidik ragam menujukkan bahwa perbedaan persentase bahan pengisi nugget ayam tidak berpengaruh nyata $(\mathrm{P}>0,05)$ terhadap tingkat kekerasan nugget ayam namun tingkat kekerasan 
tiap bahan pengisi berbeda. Hal ini disebabkan karena jumlah air pada produk dan bahan pengisi yang berbeda. Hal ini didukung Setyowati (2002) yang menyatakan bahwa kadar air yang terkandung dalam produk mempengaruhi kekerasan nugget. Semakin banyak air yang terkandung dalam produk maka semakin turun kekerasan produk tersebut.

\section{Stabilitas Emulsi}

Stabilitas emulsi merupakan indikasi kestabilan ikatan protein sebagai bahan pengikat dalam berikatan dengan minyak dan pati pada produk emulsi. Stabilitas emulsi ditentukan berdasarkan jumlah lemak yang terlepas, semakin banyak lemak yang terlepas maka emulsi semakin tidak stabil. Disamping itu, juga dipengaruhi oleh protein daging, semakin tinggi protein daging maka produk emulsi semakin stabil. Nilai rataan stabilitas emulsi nugget ayam berkisar antara 0,28 sampai 0,53 ml, berarti lemak yang terlepas dari nugget ayam relatif kecil. Stabilitas emulsi dipengaruhi oleh banyaknya lemak dan daya emulsi bahan pengikat serta imbangan protein dan lemak dalam nugget (Ulfah, 2002). Hasil analisis sidik ragam diperoleh bahwa perbedaan persentase bahan pengisi nugget ayam tidak berpengaruh nyata $(\mathrm{P}>0,05)$ terhadap stabilitas emulsi produk nugget ayam. Emulsi yang stabil ditunjukkan oleh lemak yang terpisah semakin kecil, baik selama proses penggilangan bahan menjadi adonan maupun apda saat pemanasan (Pujoraharjo, 2002). Kramlich (1971) menyatakan proses emulsifikasi menyebabkan butiran lemak akan terdispersi dalam matriks protein, kemudian protein membentuk lapisan tipis yang mengelilingi tiap-tiap butiran lemak. Pemanasab menyebabkan butiran lemak akan terperangkap di dalam matriks yang telah terbentuk suatu kantong kecil disekitar butiran lemak.

\section{Nilai pH}

Nilai pH produk diukur setelah produk nugget selesai proses pengolahannya. Analisa sidik ragam menujukkan bahwa perbedaan persentase bahan pengisi nugget ayam berpengaruh nyata $(\mathrm{P}<0,05)$ terhadap nilai $\mathrm{pH}$ nugget ayam. sagu berbeda nyata $(\mathrm{P}>0,05)$ dengan $\mathrm{pH}$ nugget ayam dengan bahan pengisi $100 \%$ tepung sagu. Nilai rataan $\mathrm{pH}$ nugget berkisar antara 4,93 sampai 5,23. Nilai pH nugget ayam ini termasuk baik karena mempunyai nilai $\mathrm{pH}<7,5$ (Ruello, 1974). Nilai $\mathrm{pH}$ tertinggi terdapat pada nugget ayam dengan bahan pengisi $100 \%$ tepung pati ubi kayu dan terendah pada nugget ayam bahan pengisi $25 \%$ tepung pati ubi kayu dan $75 \%$ tepung sagu. Proses pengukusan menyebabkan protein terdenturasi dan menghasilkan basa nitrogen yang menyebakan peningkatan pH (Tanoto, 1994) dan adanya reaksi dari gugusan reaktif dari asam amino terutama histidin yang dapat meningkatkan nilai $\mathrm{pH}$ (Forest et al, 1975).

\section{Sifat Kimia}

Pengujian yang dilakukan terhadap sifat kimia antara lain kadar air, abu, lemak, protein, dan karbohidrat. Hasil analisis sifat kimia nugget disajikan pada Tabel 4.

Tabel 4. Hasil Analisis Kimia Nugget Ayam (\%)

\begin{tabular}{lccccc}
\hline \multirow{2}{*}{ Parameter } & \multicolumn{5}{c}{ Perlakuan } \\
\cline { 2 - 6 } & P1 & P2 & P3 & P4 & P5 \\
\hline Air & 57,24 & 58,35 & 59,27 & 58,28 & 60,35 \\
Abu & $1,58^{\mathrm{a}}$ & $1,47^{\mathrm{a}}$ & $1,19^{\mathrm{b}}$ & $1,17^{\mathrm{bc}}$ & $0,99^{\mathrm{bcd}}$ \\
Protein & $9,70^{\mathrm{a}}$ & $9,81^{\mathrm{a}}$ & $8,72^{\mathrm{b}}$ & $11,11^{\mathrm{c}}$ & $8,69^{\mathrm{bd}}$ \\
Lemak & $2,25^{\mathrm{a}}$ & $2,05^{\mathrm{a}}$ & $3,30^{\mathrm{a}}$ & $5,10^{\mathrm{a}}$ & $11,51^{\mathrm{b}}$ \\
Karbohidrat & 29,23 & 28,32 & 27,52 & 24,34 & 18,46 \\
\hline
\end{tabular}

Superskrip yang berbeda pada baris yang sama menunjukkan perbedaan yang nyata $(\mathrm{P}<0,05)$ 


\section{Kadar Air}

Hasil penelitian menunjukkan bahwa perbedaan bahan pengisi tidak berpengaruh nyata $(\mathrm{P}>0,05)$ terhadap kadar air nugget. Nilai rataan kadar air nugget berkisar antara 57,24 sampai 60,35\%. Hal ini menujukkan bahwa kadar air nugget ayam yang diperoleh dari daging ayam dan penggunaan bahan pengisi yang berbeda selama proses pengolahan jumlahnya hampir sama. Kadar air tertinggi terdapat pada nugget ayam dengan bahan pengisi $100 \%$ tepung sagu dan terendah pada nugget dengan bahan pengisi $100 \%$ tepung pati ubi kayu. Rataan kadar air setiap bahan pengisi sesuai dengan persyaratan nugget ayam yaitu maksimal 60\% (SNI, 2002).

\section{Kadar Abu}

Hasil penelitian menunjukkan bahwa perbedaan bahan pengisi berpengaruh nyata $(\mathrm{P}<0,05)$ terhadap kadar abu nugget. Kadar abu nugget berkisar antara 0,99 sampai 1,58\%. Kadar abu tertinggi diperoleh pada nugget dengan bahan pengisi 100\% tepung pati ubi kayu dan kadar abu terendah pada nugget dengan bahan pengisi $100 \%$ tepung sagu. Semakin tinggi level penggunaan tepung sagu maka kadar abu nugget semakin kecil. Hal ini disebabkan perbedaan kadar abu dari tepung pati ubi kayu dan tepung sagu sehingga dapat mempengaruhi kadar abu dari nugget yang dihasilkan.

\section{Kadar Protein}

Hasil penelitian menunjukkan bahwa perbedaan bahan pengisi berpengaruh nyata $(\mathrm{P}<0,05)$ terhadap kadar protein nugget. Nilai rataan kadar protein berkisar antara 8,72 sampai 11,11\%. SNI (2002) mensyaratkan kadar protein nugget minimal $12 \%$ dan kadar protein dalam penelitian ini diperoleh tidak ada yang memenuhi persyaratan SNI. Namun, pada nugget dengan bahan pengisi $25 \%$ tepung pati ubi kayu dan 75\% tepung sagu mengandung protein yang mendekati persyaratan SNI (2002) yaitu sebesar 11,11\%.

\section{Kadar Lemak}

Hasil penelitian menunjukkan bahwa perbedaan bahan pengisi berpengaruh nyata $(\mathrm{P}<0,05)$ terhadap kadar lemak nugget. Nilai rataan kadar lemak berkisar nugget antara 2,05\%-11,15\%. Kadar lemak tertinggi terdapat pada nugget dengan bahan pengisi 100\% tepung sagu dan terendah pada nugget dengan bahan pengisi 100\% tepung sagu. Kadar lemak makanan bervariasi mulai dari sangat rendah sampai sangat tinggi (deMan, 1997). Berdasarkan analisa sidik ragam menujukkan bahwa perbedaan persentase tepung tapioka dan tepung sagu berpengaruh nyata terhadap kadar lemak nugget. Nugget ayam dengan bahan pengisi 100\% tepung tapioka, 25\% tepung tapioka dan 75\% tepung sagu, $50 \%$ tepung tapioka dan 50\% tepung sagu, 75\% tepung tapioka dan $25 \%$ tepung sagu berbeda nyata $(\mathrm{P}>0,05)$ dengan nugget ayam pada bahan pengisi $100 \%$ tepung sagu.

\section{Kadar Karbohidrat}

Hasil penelitian menunjukkan bahwa perbedaan bahan pengisi berpengaruh nyata $(\mathrm{P}<0,05)$ terhadap kadar karbohidrat nugget. Nilai rataan kadar karbohidrat maka berkisar antara 18,46 sampai 29,23\%. Persyaratan nugget ayam menurut SNI (2002) untuk kadar karbohidrat maksimal 25\%, dengan demikian yang memenuhi syarat adalah nugget pada bahan pengisi $25 \%$ tepung pati ubi kayu dan $75 \%$ tepung sagu serta nugget dengan bahan pengisi 100\% tepung sagu. Bahan pengisi lain melebihi persyaratan SNI (2002) dan yang paling jauh dari persyaratan adalah nugget bahan pengisi 100\% tepung 
sagu. Hal ini disebabkan kadar karbohidrat tepung pati ubi kayu 86,9\% lebih besar daripada tepung sagu 84,7\% (Direktorat Gizi Depkes RI, 1995).

\section{Sifat Organoleptik}

Pengukuran kualitas suatu produk pangan dapat dilakukan dengan menggunakan panca indra. Uji hedonik atau uji kesukaan termasuk dalam kelompok uji penerimaan. Uji penerimaan menyangkut penilaian seseorang akan suatu sifat atau kualitas suatu produk. Uji hedonik bertujuan untuk mengetahui respon panelis terhadap sifat mutu yang umum, misalnya penampakan, aroma, rasa, tekstur, dan warna (Soekarto, 1985). Hasil uji hedonik nugget ayam disajikan pada Tabel 5.

Tabel 5. Hasil Analisis Sifat Organoleptik Nugget Ayam

\begin{tabular}{lccccc}
\hline \multirow{2}{*}{ Parameter } & \multicolumn{5}{c}{ Perlakuan } \\
\cline { 2 - 6 } & P1 & P2 & P3 & P4 & P5 \\
\hline Penampakan & $2,20^{\mathrm{a}}$ & $2,34^{\mathrm{a}}$ & $2,59^{\mathrm{bc}}$ & $2,44^{\mathrm{ac}}$ & $2,60^{\mathrm{bc}}$ \\
Warna & $2,50^{\mathrm{a}}$ & $2,63^{\mathrm{a}}$ & $3,13^{\mathrm{b}}$ & $3,14^{\mathrm{b}}$ & $3,27^{\mathrm{b}}$ \\
Tektur & $2,24^{\mathrm{a}}$ & $2,24^{\mathrm{a}}$ & $2,33^{\mathrm{a}}$ & $3,02^{\mathrm{b}}$ & $3,17^{\mathrm{b}}$ \\
Aroma & $2,06^{\mathrm{a}}$ & $2,24^{\mathrm{ac}}$ & $2,53^{\mathrm{b}}$ & $2,98^{\mathrm{bc}}$ & $2,80^{\mathrm{b}}$ \\
Rasa & $2,20^{\mathrm{a}}$ & $2,34^{\mathrm{a}}$ & $2,58^{\mathrm{b}}$ & $2,44^{\mathrm{b}}$ & $2,63^{\mathrm{b}}$ \\
\hline
\end{tabular}

abcd Superskrip yang berbeda pada baris yang sama menunjukkan perbedaan yang nyata $(\mathrm{P}<0,05)$

\section{Penampakan}

Hasil penelitian menunjukkan bahwa perbedaan bahan pengisi berpengaruh nyata $(\mathrm{P}<0,05)$ terhadap penampakan nugget. Nilai rataan penampakan nugget ayam berkisar antara 2,20 sampai 2,60 berarti panelis menyukai penampakan nugget pada penelitian ini. Penampakan yang paling disukai panelis adalah nugget dengan bahan pengisi 100\% tepung pati ubi kayu. Karakteristik pertama yang dinilai konsumen dalam mengkonsumsi suatu produk adalah penampakan produk itu baik atau tidak karena sifat mutu komoditas dinilai dengan penglihatan seperti bentuk, ukuran dan warna (Soekarto, 1990).

\section{Warna}

Hasil penelitian menunjukkan bahwa perbedaan bahan pengisi berpengaruh nyata $(\mathrm{P}<0,05)$ terhadap warna nugget. Warna merupakan hasil dari indra mata yang memberikan pertimbangan terhadap produk yang akan dinilai. Warna juga penting dalam makanan baik yang diproses dan warna juga memberi petunjuk mengenai perubahan kimia dalam makanan seperti pencoklatan (deMan, 1977). Nilai rataan uji organoleptik warna nugget berkisar antara 2,50 sampai 3,27 yang berarti nugget ayam tersebut masih dapat diterima oleh panelis. Warna nugget dengan bahan pengisi $100 \%$ tepung sagu memiliki nilai warna yang paling tinggi yaitu 3,27. Menurut Winarno (1991) warna akhir dari produkproduk emulsi daging sebagian besar diakibatkan oleh proses karamelisasi dan reaksi pencoklatan. Fardiaz et al (1992) menyatakan bahwa produk-produk dari pati memberi warna kecoklatan bila dipanaskan. Warna kecoklatan disebabkan poridekstrin yaitu pati yang mengandung dekstrin pada saat dipanaskan akan terpolimerisasi membentuk warna coklat. Owen (2001) menyatakan konsumen lebih menyukai warna nugget yang cerah.

\section{Tekstur}

Hasil penelitian menunjukkan bahwa perbedaan bahan pengisi berpengaruh nyata $(\mathrm{P}<0,05)$ terhadap tekstur nugget. Tekstur adalah salah satu faktor yang mempengaruhi pilihan konsumen terhadap suatu bahan pangan. Nilai tekstur nugget berkisar antara 2,24 sampai 3,17 yang berarti nugget 
ayam tersebut masih dapat diterima oleh panelis. Tekstur nugget dengan bahan pengisi 100\% tepung sagu memiliki nilai tekstur yang paling tinggi yaitu 3,17. Hal ini disebabkan oleh kadar karbohidrat yang berbeda dari masing-masing bahan pengisi yang digunakan yaitu tepung pati ubi kayu dan tepung sagu.

\section{Aroma}

Hasil penelitian menunjukkan bahwa perbedaan bahan pengisi berpengaruh nyata $(\mathrm{P}<0,05)$ terhadap aroma nugget. Salah satu faktor yang menetukan suatu makanan dapat diterima oleh konsumen adalah aroma. Aroma makanan menetukan kelezatan makanan tersebut (Winarno, 1991). Hasil pengujian diperoleh nilai rataan aroma nugget ayam berkisar antara 2,06 sampai 2,96. Menurut Wilson (1960) aroma pada suatu produk dapat ditingkatkan karena adanya penambahan rempahrempah yang berfungsi sebagai flavor, rempah-rempah yang digunakan adalah merica, selain itu aroma juga dipengaruhi oleh kadar lemak dan jenis tepung yang digunakan. Aroma nugget dengan bahan pengisi $25 \%$ tepung pati ubi kayu dan $75 \%$ tepung sagu memiliki nilai warna yang paling tinggi yaitu 2,96 .

\section{Rasa}

Hasil penelitian menunjukkan bahwa perbedaan bahan pengisi berpengaruh nyata $(\mathrm{P}<0,05)$ terhadap rasa nugget. Rasa merupakan salah satu faktor yang mempengaruhi nilai penerimaan seseorang terhadap makanan. Nilai rataan aroma nugget ayam berkisar antara 2,2 sampai 2,63. Nugget ayam yang lebih disukai oleh panelis adalah nugget dengan bahan pengisi $100 \%$ tepung pati ubi kayu. Penerimaan panelis terhadap rasa dipengaruhi oleh beberapa faktor, antara lain senyawa kimia, suhu, konsentrasi dan interaksi dengan komponen lainnya (Winarno, 1991).

\section{KESIMPULAN}

Tepung pati ubi kayu lokal dapat menggantikan 100\% tepung tapioka komersil dan tepung sagu dapat mensubtitusi tepung tapioka komersil sampai 50\% untuk mendapatkan nugget yang berkualitas, sehingga dapat disimpulkan bahwa tepung pati ubi kayu dan tepung sagu lokal yang ada di Provinsi Maluku Utara dapat dijadikan sebagai bahan pengisi nugget ayam.

\section{DAFTAR PUSTAKA}

AOAC. (1995). Official Methods of Analyses. 16 Ed. Washington, DC: Association of Official Analytical Chemists

Astawan, M. (2004). Tetap Sehat dengan Produk Makanan Olahan. Solo: Tiga Serangkai.

deMan, J. M. (1997). Kimia Pangan. Bandung: Institut Teknologi Bandung.

Direktorat Gizi Depkes R.I. (1989). Daftar Komposisi Bahan Makanan. Jakarta: Bharata Karya Aksara.

Fardiaz, D., Andarwulan, N., Wijaya, H. \& Puspatasari, N. L. (1992). Teknik Analisis Sifat Kimia dan Fungsional Komponen Pangan. Bogor: Pusat Antar Universitas Pangan dan Gizi Institut Pertanian Bogor.

Forest, J. C., Aberle, E. D., Hendrick, H. B., Judge, M. D. \& Markel, R. A. (1975). Principle of Meat Science. San Francisco: Freeman and Co.

Rieuwpassa, F. J. (2016). Karakteristik kimia dan nilai organoleptik nugget ikan tuna dengan subtitusi tepung sagu. Jurnal Ilmiah Tindalung, 2(2), 103-111.

Kilcast, D. \& Eves, A. (1993). Instrumentation and Sensors for The Food Industry. Butterwort Hineman: Oxford. 
Kramlich, W. E., Pearson, A. M., \& Tauber, F.W. (1971). Processor Meat. Westport: AVI Publ. Co. Inc.

Kusumaningrum, M. K. (2013). Pengaruh berbagai filler (bahan pengisi) terhadap kadar air, rendemen dan sifat organoleptik (warna) chicken nugget. Animal Agriculture Journal, 2 (1), 370-376.

Muljohardjo, M. (1987). Teknologi Pengolahan Pati. Yogyakarta: Pusat Antar Universitas Pangan dan Gizi Universitas Gadjah Mada.

Ockerman, H. W. (1983). Chemistry of Meat Tissue, 10th Ed. Dept. Of Animal science. Ohio: The Ohio State University and The Ohio Agricultural Research and Development Center.

Awaliah, R., Yanto, S. \& Sukainah. A. (2017). Analisis sifat fisiko kimia nugget rajungan (portunuspelagicus) dengan berbagai jenis tepung sebagai bahan pengisi. Jurnal Pendidikan Teknologi Pertanian, 3, 148-155.

Sakul, S. \& Komansilan, S. (2018). Pengaruh penggunaan beberapa jenis filler terhadap palatabilitas chicken nugget ayam petelur afkir. Zootec, 38(2), 368-378.

SNI. (2002). Nugget Ayam. Jakarta: Badan Standarisasi Nasional Indonesia

Soekarto, S. T. (1985). Penilaian Organoleptik Untuk Industri Pangan dan Hasil Pertanian. Jakarta : Penerbit Bhratara Karya Aksara.

Soekarto, S. T. \& Hubeis, M. (1992). Petunjuk Laboratorium Metode Penelitian Indrawi. Bogor: Pusat Antar Universitas Pangan dan Gizi, Insitut Pertanian Bogor.

Soeparno, (1992). Ilmu dan Teknologi Daging. Yogyakarta: Gadjah Mada University Press.

Suarni. (2009). Prospek pemanfaatan tepung jagung untuk kue kering (Cookies). Jurnal Litbang Pertanian, 28(2), 63-71.

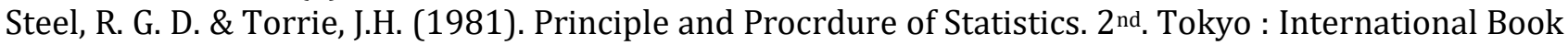
Company.

Sudarmaji, S., Haryono, B. \& Suhardi. (1997). Prosedur Analisa untuk Bahan Makanan dan Pertanian. Yogyakarta: Liberty.

Tanoto, E. (1994). Pengolahan Fish Nugget dari Ikan Tenggiri. Skripsi. Teknologi Pangan dan Gizi, Bogor: Fakultas Teknologi Pertanian, Instut Pertanian Bogor.

United States Department of Agriculture (USDA). (1991). Food Safety Inspection Service, Processing Inspector's Calculation HandBook. USA: Administrative Management Human Resource Development Division.

Winarno, F.G. (1993). Gizi, Teknologi dan Konsumen. Jakarta: PT Gramedia Pustaka Utama.

Winarno, F.G. (1997). Kimia pangan dan Gizi. Jakarta: PT Gramedia Pustaka Umum. 